\title{
Enhanced apoptotic effect of combined modality of 9-hydroxypheophorbide $\alpha$-mediated photodynamic therapy and carboplatin on AMC-HN-3 human head and neck cancer cells
}

\author{
PEIJIE HE ${ }^{1-3}$, JIN-CHUL AHN ${ }^{1,2}$, JANG-IN SHIN ${ }^{2}$, HEE-JUN HWANG ${ }^{2}$, \\ JUNG-WOOK KANG ${ }^{2}$, SANG-JOON LEE ${ }^{1}$ and PHIL-SANG CHUNG ${ }^{1,2}$ \\ ${ }^{1}$ Department of Otolaryngology-Head and Neck Surgery, ${ }^{2}$ Medical Laser Research Center, College of Medicine, \\ Dankook University, Cheonan, Chungnam 330-715, Korea; ${ }^{3}$ Department of Otolaryngology-Head and Neck \\ Surgery, affiliated Eye, Ear, Nose and Throat Hospital, Fudan University, Shanghai 200031, P.R. China
}

Received July 2, 2008; Accepted September 17, 2008

DOI: 10.3892/or_00000225

\begin{abstract}
Photodynamic therapy (PDT) has been developed as an effective treatment for malignant disease. Carboplatin (CBDCA), a less nephrotoxic analog of cisdiamminedichloroplatinum (cisplatin), has been widely used for the treatment of multiple malignancies. In this study, we investigated the cytotoxic and apoptotic effect of combined modality of 9-hydroxypheophorbide $\alpha$ (9-HPbD)-mediated PDT and CBDCA on AMC-HN-3 human head and neck cancer cell line in vitro. The attached $\mathrm{AMC}-\mathrm{HN}-3$ cells were incubated with CBDCA $(0.04 \mathrm{mg} / \mathrm{ml})$ for $24 \mathrm{~h}$ at $37^{\circ} \mathrm{C}$ and followed by photosensitization with $9-\mathrm{HPbD}$ for $6 \mathrm{~h}$ and laser irradiation with $670 \mathrm{~nm}$ diode laser at an intensity of $2.0 \mathrm{~J} / \mathrm{cm}^{2}$ for activating $9-\mathrm{HPbD}$ for $15 \mathrm{~min}$. Then MTT reduction assay and Hoechst 33342 and propidium iodide (PI) double staining were used respectively to measure the cytotoxicity and nuclear morphology at $24 \mathrm{~h}$ after PDT. Expression of caspase-3, -9 and poly(ADP-ribose) polymerase (PARP) was detected at 0, 3, 6 and $12 \mathrm{~h}$ after irradiation through Western blotting techniques. Compared with PDT and CBDCA alone groups, there was more cytotoxicity and enhanced apoptotic cell death in combination groups. The peaked expression of cleaved form of caspase-3, -9 and PARP occurred $\sim 3 \mathrm{~h}$ after PDT. There was stronger expression of cleaved caspase-3, -9 and PARP in combination groups than that in PDT or CBDCA alone groups. This study demonstrates that the combined modality resulted in enhanced apoptotic cell death as well as cytotoxic effect on AMC-HN-3 cells in vitro, which suggests the
\end{abstract}

Correspondence to: Dr Phil-Sang Chung, Department of Otolaryngology-Head and Neck Surgery, College of Medicine, Dankook University, Cheonan, Chungnam 330-715, Korea

E-mail: pschung@dankook.ac.kr

Key words: photodynamic therapy, 9-hydroxypheophorbide $\alpha$, carboplatin, apoptosis feasibility of combined modality and the possibility of reducing the effective dosage of $9-\mathrm{HPbD}$ and $\mathrm{CBDCA}$ and lowering the side effects on normal cells.

\section{Introduction}

Photodynamic therapy (PDT) is a relative new treatment modality for various types of cancer (1). This approach is based on the local or systemic administration and the selective accumulation and/or retention of a photosensitizing agent (photosensitizer) in tumor tissue followed by irradiation with visible light of a wavelength matching the absorption spectrum of the photosensitizer (therapeutic window: 600-800 nm) (1-4).

Absorption of light by the photosensitizer initiates the photochemical generation of cytotoxic singlet oxygen within the irradiated field, which results in cancer cell death through oxidative damage of a variety of cellular organelles $(1,2,5)$. Studies have suggested that PDT can trigger apoptosis in vitro (6) or in vivo (7). A clinical study showed novel effect of PDT in early-stage squamous cell carcinoma of the head and neck (8). However, long-lasting cutaneous photosensitivity is unavoidable, as the photosensitizer is absorbed by the skin $(8,9)$, which impacts the acceptability of PDT to malignant tumor therapy.

Carboplatin (CBDCA), a less nephrotoxic analog of cisdiamminedichloroplatinum (cisplatin), has been established as a highly potent therapeutic agent for malignant tumors, including head and neck, ovarian, esophageal and non-small lung cell cancers (10-13). Apart from being useful, it shows toxicity to the human body and leads to inevitable side effects such as dose-dependent cumulative myelosuppression (14-17), nausea and/or vomiting (14).

In this study, we assessed the cytotoxic and apoptotic effect of combined treatment with 9-hydroxypheophorbide $\alpha$ (9-HPbD) (18) mediated PDT and CBDCA on Asan Medical Center-Head and Neck-3 (AMC-HN-3) cancer cells (19) in vitro. We also investigated the possibility to reduce the effective dosage for these agents and to lower their side effects on normal cells. 


\section{Materials and methods}

Chemicals and antibodies. 9-HPbD, a novel chlorophyllderived photosensitizer (18), was provided by Kumho Life and Environmental Science Laboratory (Kwangju, Korea). A stock solution $(1.5 \mathrm{mg} / \mathrm{ml})$ was made in ethanol and kept in aluminum foil at $-20^{\circ} \mathrm{C}$. $9-\mathrm{HPbD}$ was diluted in the culture medium just before being used and then added to exponentially growing cells. For cell culture, all medium supplements, i.e., RPMI, fetal bovine serum (FBS) and antibiotics were supplied by Hyclone (South Logan, UT, USA). 3-[4,5-dimethylthiazol-2-yl]-2,5-diphenyl-tetrazolium bromide (MTT), dimethyl sulfoxide (DMSO), Hoechst (33342) dye, Propidium iodide (PI) dye, RIPA buffer, protease and phosphatase inhibitors were purchased from Sigma (Saint Louis, MO, USA). Bradford Dye Reagent was supplied by Bio-Rad (Hercules, CA, USA). Caspase-3 (235412), poly(ADP-ribose) polymerase (PARP) (AM30), caspase-9 (sc-8355) and GAPDH (ab9485) were purchased from Calbiochem (Darm Stadt, Germany), SantaCruz (CA, USA) and Abcam (Cambridge, UK), respectively.

Cell cultures and PDT/CBDCA treating protocols. AMCHN-3 cell line was kindly donated by Asan Medical Center (Seoul, South Korea), which was developed from a 63-yearmale patient with previously untreated laryngeal squamous cell carcinoma (19). AMC-HN-3 cells $\left(2 \times 10^{5}\right.$ cells/well) seeded in 96-well microplates or culture dishes attached well to the flat bottom after being incubated in RPMI medium containing $10 \% \mathrm{FBS}$ and $1 \%$ antibiotics (streptomycin and penicillin) at $37^{\circ} \mathrm{C}$ in a $\mathrm{CO}_{2}$ incubator for $24 \mathrm{~h}$. For the PDT study, various concentrations of $9-\mathrm{HPbD}(0-9.38 \mu \mathrm{g} / \mathrm{ml})$ were added to culture medium and cells were incubated for $6 \mathrm{~h}$ under dark conditions. Then the photosensitized cells were exposed to $670 \mathrm{~nm}$ diode laser at an intensity of 2.0 $\mathrm{J} / \mathrm{cm}^{2}$ for activating $9-\mathrm{HPbD}$ for $15 \mathrm{~min}$. After irradiation, the cells were returned to a $37^{\circ} \mathrm{C}$ dark incubator for $3-24 \mathrm{~h}$ according to the time point required. For the CBDCA alone group and combined PDT with CBDCA groups, the attached cells were incubated with CBDCA $(0.04 \mathrm{mg} / \mathrm{ml})$ for $24 \mathrm{~h}$ at $37^{\circ} \mathrm{C}$ first, then followed by PDT or not according to the procedure mentioned in Fig. 1.

Cell viability assay. MTT reduction assay was used to measure the cell viability of AMC-HN-3 cells after PDT and/or CBDCA treatment. Briefly, $24 \mathrm{~h}$ after irradiation, the cells were incubated with MTT $(0.5 \mathrm{mg} / \mathrm{ml})$ for $2 \mathrm{~h}$ at $37^{\circ} \mathrm{C}$, then the medium was discarded and DMSO was added. After $20 \mathrm{sec}$ of incubation and shaking, absorbance at wavelengths of $540 \mathrm{~nm}$ was measured using a microplate reader (Bio-Rad, Hercules). The percentage of cell viability was calculated using the following equation: cell viability $(\%)=$ Mean absorbance $\left._{\text {treatment group }}\right) /$ Mean absorbance control group $\mathrm{x} 100$.

Hoechst and PI double staining. Cells were plated in 35-mm dishes and treated as described above. Twenty-four hours after laser irradiation, morphological changes on the nuclear chromatin of cells undergoing apoptosis were detected by double-staining with Hoechst 33342 and PI. Briefly, the cells

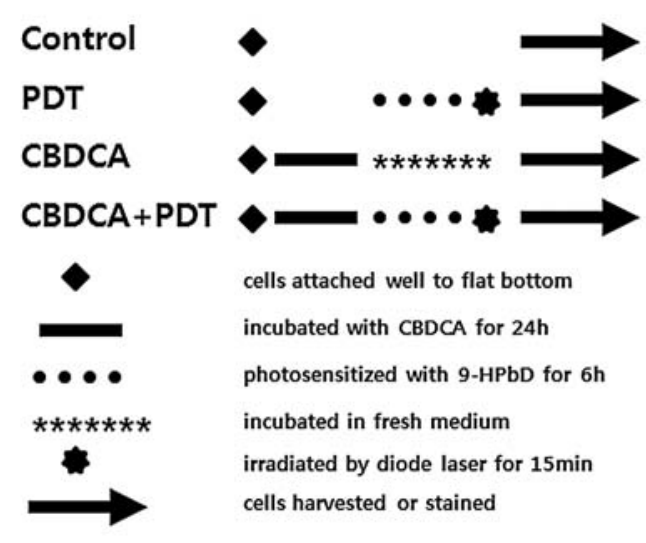

Figure 1. The same time course showed in the illustrative protocol was shared by different groups.

were incubated with Hoechst $33342(2 \mu \mathrm{g} / \mathrm{ml})$ in medium for $30 \mathrm{~min}$. Then the medium was changed to a fresh one and the cells were incubated with PI $(2 \mu \mathrm{g} / \mathrm{ml})$ for $10 \mathrm{~min}$. The stained cells were observed to measure apoptosis and necrosis using a laser scanning confocal microscope (Zeiss LSM510 META, Germany).

Hoechst 33342 is a fluorescent dye that specifically stains nucleic acid. Normal cells stained with Hoechst showed normal morphology of nuclei (blue), while apoptotic cells showed shrinkage or condensation nuclei (bright blue). PI can be resisted by the intact cytoplasmic membrane of normal and early apoptotic cells, but can penetrate the cytoplasmic membrane of oncotic cells (late apoptotic and necrotic cells) and stain the nuclei pink.

Western blotting. PDT and/or CBDCA treated AMC-HN-3 cells were harvested and the expression of caspase-3, -9 and PARP in the cells was analyzed using the Western blot techniques. After PDT and/or CBDCA treatment, the cells were washed with cold DPBS twice and then the proteins were extracted in RIPA buffer [50 mM Tris- $\mathrm{HCl}, \mathrm{pH} 8.0$, with $150 \mathrm{mM}$ sodium chloride, 1.0\% lgepal CA-630(NP40), $0.5 \%$ sodium deoxycholate, and $0.1 \%$ sodium dodecyl sulfate, protease and phosphatase inhibitor cocktail]. Protein concentrations were determined using Bradford dye reagent. One fourth of the sample volume of 5X SDS sample buffer was added to the cell lysate. Equivalent amounts of protein $(100 \mu \mathrm{g})$ were loaded onto $10 \%$ polyacrylamide gels, subjected to electrophoresis, and transferred to PVDF membrane. Electrophoresis and blotting were both performed using the PowerPac200 electrophoresis system (Bio-Rad, Hercules). After blocking with 5\% non-skimmed milk for $1 \mathrm{~h}$, primary antibodies were bound overnight at $4^{\circ} \mathrm{C}$. The membranes were probed with horseradish peroxidase-conjugated anti-mouse IgG or anti-rabbit IgG antibody for $1 \mathrm{~h}$. The protein band was detected by Kodak in vivo image analyzer.

\section{Results}

Cytotoxicity of 9-HPbD-mediated PDT and CBDCA. To determine the combined anti-cancer effect of PDT and CBDCA treatment on AMC-HN-3 cells, MTT reduction assay 


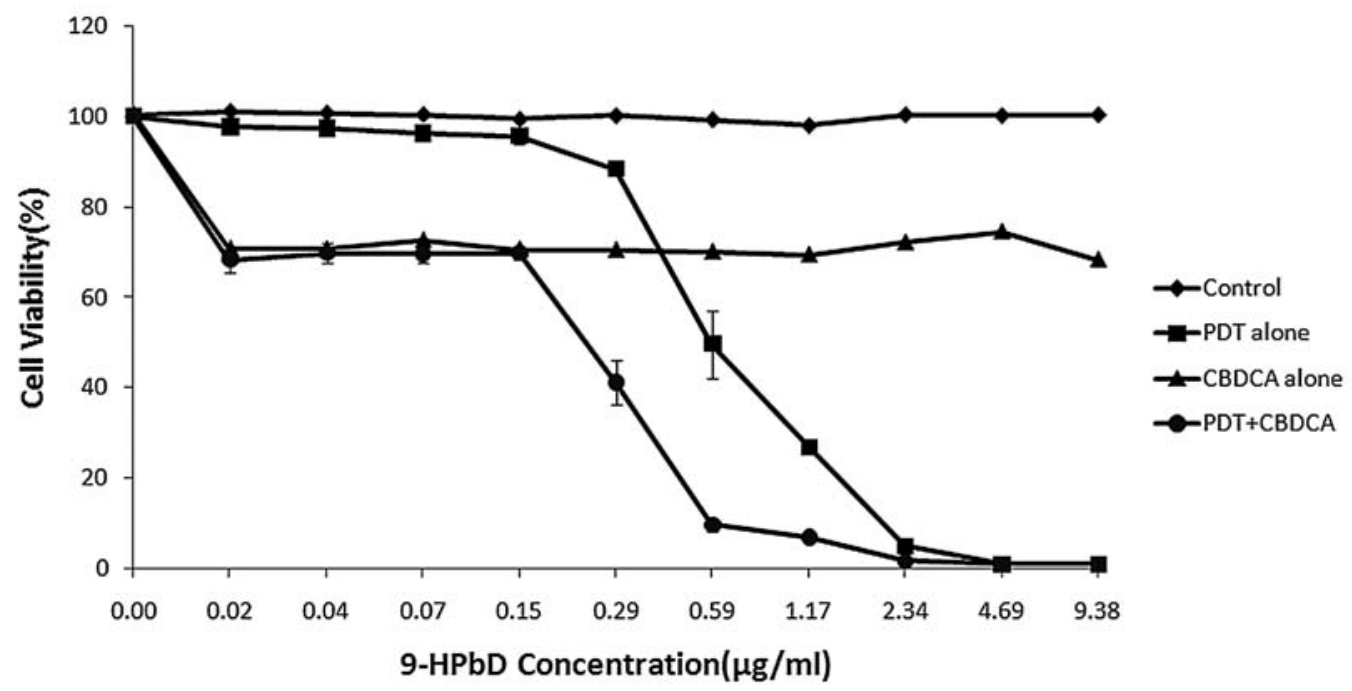

Figure 2. Phototoxicity was determined by MTT assay $24 \mathrm{~h}$ after laser irradiation. Combined PDT with CBDCA shows more cytotoxicity to AMC-HN-3 cells compared with PDT and CBDCA alone.
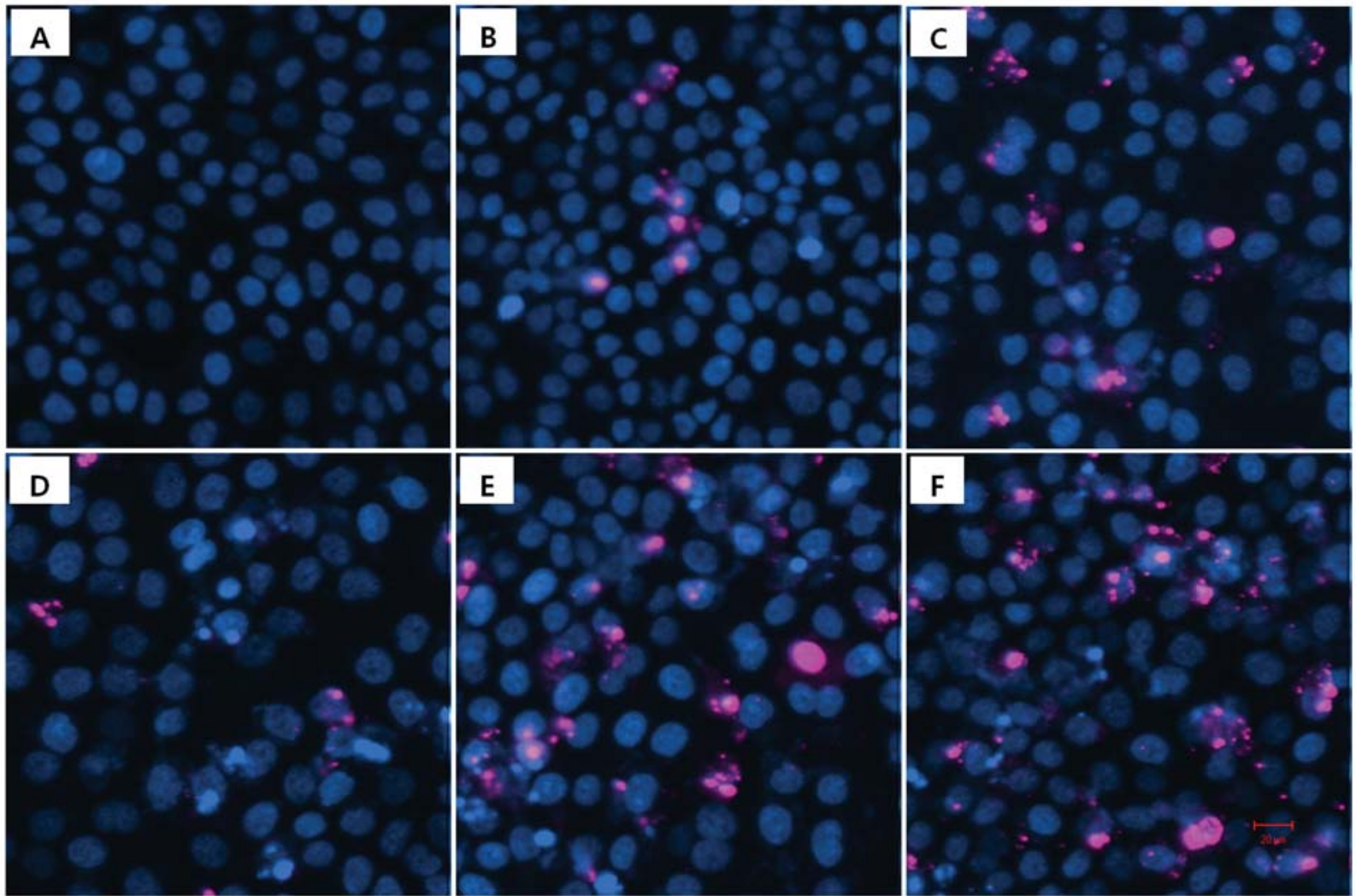

Figure 3. Morphological characterization of AMC-HN-3 cells induced by PDT and/or CBDCA was measured by Hoechst and PI double staining. Representative fluorescent microscopic images of $\mathrm{Hoechst}^{+}$(blue) and Hoechst ${ }^{+} / \mathrm{PI}^{+}$(pink) staining were obtained using a laser scanning confocal microscope. Early apoptotic cells show asymmetric Hoechst 33342 staining (bright blue) of their nuclei as a result of chromatin condensation and nuclear fragmentation, and late apoptotic cells were stained by Hoechst 33342 and PI (pink) with asymmetric nuclei staining. Pink intact nuclei were considered as necrotic cells. (A), control (no treatment); (B), PDT (9-HPbD $0.29 \mu \mathrm{g} / \mathrm{ml}$ ) alone; (C), PDT (9-HPbD $0.59 \mu \mathrm{g} / \mathrm{ml}$ ) alone; (D), CBDCA (0.04 mg/ml) alone; (E), PDT $(9-\mathrm{HPbD} 0.29 \mu \mathrm{g} / \mathrm{ml})+\mathrm{CBDCA}(0.04 \mathrm{mg} / \mathrm{ml})$ and $(\mathrm{F})$, PDT $(9-\mathrm{HPbD} 0.59 \mu \mathrm{g} / \mathrm{ml})+\mathrm{CBDCA}(0.04 \mathrm{mg} / \mathrm{ml})$. Scale bar $(20 \mu \mathrm{m})$ in (F) for (A-F)

were first used to assess the photocytotoxicity at $24 \mathrm{~h}$ after laser irradiation. The extent of phototoxicity was dependent on the concentration of $9-\mathrm{HPbD}$. Cell viability induced by combination group was 41.3 and $9.8 \%$ at the concentration of $9-\mathrm{HPbD} 0.29 \mu \mathrm{g} / \mathrm{ml}$ and $0.59 \mu \mathrm{g} / \mathrm{ml}$ respectively, whereas there was 88.4 and $49.8 \%$ cell viability at the same concentration of $9-\mathrm{HPbD}$ in PDT alone groups. Dividing the effect of CBDCA alone, there was $\sim 17.6$ and $10.1 \%$ extra cytotoxic effect at the concentration of 9-HPbD $0.29 \mu \mathrm{g} / \mathrm{ml}$ and $0.59 \mu \mathrm{g} / \mathrm{ml}$ respectively in combination groups (Fig. 2). 
A

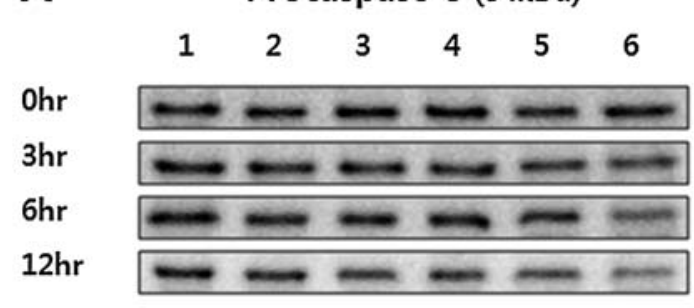

C

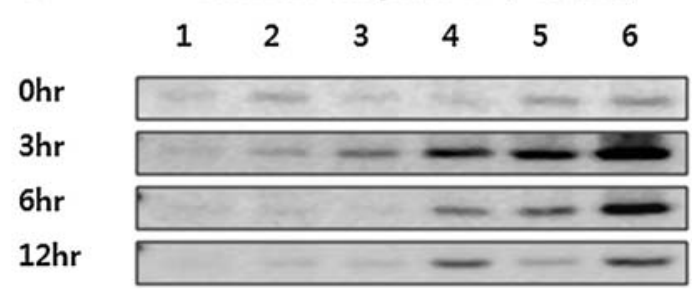

E

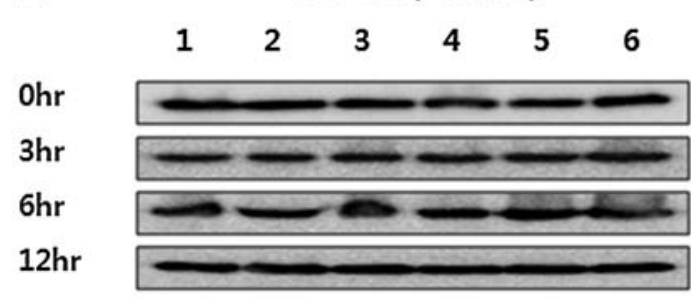

B

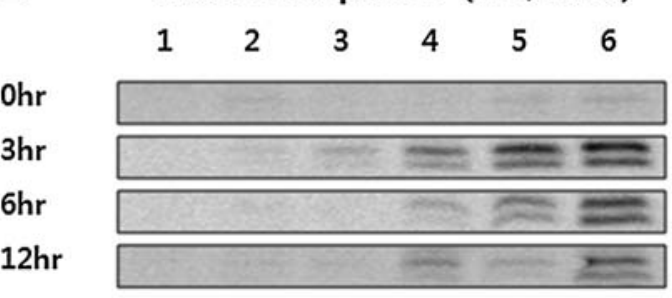

D

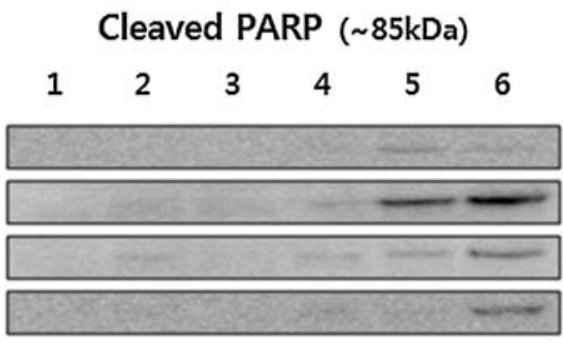

Figure 4. Expression of caspase-3 (A and B), caspase-9 (C), PARP (D) and GAPDH (E) in AMC-HN-3 head and neck cancer cells at 0, 3, 6 and $12 \mathrm{~h}$ after PDT combined with CBDCA or not. In CBDCA alone group, the cells were incubated with CBDCA $(0.04 \mathrm{mg} / \mathrm{ml})$ for $24 \mathrm{~h}$, then cell lysates were prepared at $6,9,12$ and $18 \mathrm{~h}$ after being incubated with fresh medium. In PDT and combination group, AMC-HN-3 cells were sensitized with $9-\mathrm{HPbD}(0.29 \mu \mathrm{g} / \mathrm{ml}$ or $0.59 \mu \mathrm{g} / \mathrm{ml})$ for $6 \mathrm{~h}$, and then followed by laser irradiation $\left(2.0 \mathrm{~J} / \mathrm{cm}^{2}\right)$ and preparation of cell lysates at $0,3,6$ and $12 \mathrm{~h}$ after PDT. For combination group, the cells were incubated with CBDCA $(0.04 \mathrm{mg} / \mathrm{ml})$ for $24 \mathrm{~h}$ before cell photosensitization. Lane 1, control (no treatment); lane 2, CBDCA $(0.04 \mathrm{mg} / \mathrm{ml})$ alone; lane 3, PDT (9-HPbD $0.29 \mu \mathrm{g} / \mathrm{ml})$ alone; lane 4, PDT (9-HPbD $0.59 \mu \mathrm{g} / \mathrm{ml})$ alone; lane 5, PDT $(9-\mathrm{HPbD} 0.29 \mu \mathrm{g} / \mathrm{ml})+\mathrm{CBDCA}(0.04 \mathrm{mg} / \mathrm{ml})$ and lane 6, PDT (9-HPbD $0.59 \mu \mathrm{g} / \mathrm{ml})+$ CBDCA $(0.04 \mathrm{mg} / \mathrm{ml})$.

Apoptotic and necrotic cell death induced by PDT and $C B D C A$. Hoechst 33342 and PI double staining was used to assess apoptotic and necrotic cell death $24 \mathrm{~h}$ after PDT. Intact homogeneous blue nuclei, condensed/fragmented blue nuclei, condensed/fragmented pink nuclei, and pink intact nuclei were considered as viable, early apoptotic, late apoptotic, and necrotic cells, respectively.

The cells in control group showed intact homogeneous blue and round nuclei (Fig. 3A). There were only infrequent condensed/fragmented blue and pink nuclei observed at lower dose of 9-HPbD $(0.29 \mu \mathrm{g} / \mathrm{ml})$-mediated PDT alone group (Fig. 3B), comparing with more condensed/fragmented blue and pink nuclei and some pink intact nuclei at higher dose $(0.59 \mu \mathrm{g} / \mathrm{ml})$ group (Fig. 3C). The cells of CBDCA treatment alone group displayed condensed blue nuclei with chromatin packed at the periphery and fragmented blue nuclei, as well as sporadic condensed/fragmented pink nuclei (Fig. 3D). There were more condensed/fragmented blue and pink nuclei in combination groups (Fig. 3E and F) than those in PDT and CBDCA alone groups (Fig. 3B-D). Some pink intact nuclei consistent with the dose of $9-\mathrm{HPbD}$ were observed in combination groups (Fig. 3E and F).

Activation of caspase-3, -9 and PARP. Western blotting revealed decreasing expression of the precursor of caspase- 3 from 0 to $12 \mathrm{~h}$ after laser irradiation in PDT alone and combination groups (Fig. 4A), and increasing expression of cleaved form of caspase- 3 from 0 to $3 \mathrm{~h}$ and then decreasing expression from 3 to $12 \mathrm{~h}$ in these groups. The peaked

expression of cleaved caspase- 3 occurred around $3 \mathrm{~h}$ after laser irradiation. There was stronger expression of cleaved caspase- 3 in combination group than that in PDT or CBDCA alone group (Fig. 4B). Caspase-9 and PARP, the upstream mediator and the native substrate of caspase- 3 respectively, demonstrated similar expression pattern with cleaved caspase-3 (Fig. 4C and D, respectively).

\section{Discussion}

As a less nephrotoxic analog of cisplatin, although CBDCA is highly effective against some tumors, it has inevitable problems such as side effects and inherent or acquired resistance during treatment (14-17).

PDT is a minimally invasive therapeutic modality clinically approved for treatment of cancer which is based on the accumulation of photosensitizing molecules in tumor tissue and the local activation of the photosensitizer by exposure to visible light. Most of the photosensitizers used are effective, but showed skin phototoxicity $(8,9)$. Previously, new photosensitizers were developed for PDT to overcome shin phototoxicity $(18,20-23)$, 9-HPbD, a novel pheophorbide-based photosensitizer as a chlorophyll derivative, was used in this study for PDT on AMC-HN-3 cells to investigate whether or not the increased cytotoxicity and the enhanced apoptosis can be obtained through combining with CBDCA. The combination treatment was expected to 
reduce the effective dose of these agents and maybe to lower toxic effects including skin phototoxicity on normal cells.

As shown in Fig. 2, the cell death percentage for combined treatment was more than the sum of that of PDT and CBDCA treatment alone either in higher or lower dose of $9-\mathrm{HPbD}$, which is suggestive of a synergistic cytotoxic effect for PDT and CBDCA. There was a significantly increased number of condensed/fragmented blue nuclei (early stage of apoptosis) and condensed/fragmented pink nuclei (late stage of apoptosis) in combination groups (Fig. 3E and F) than those in PDT and CBDCA alone groups (Fig. 3B-D). Moreover, pink intact nuclei (necrotic cells) appeared in PDT (9-HPbD 0.59 $\mu \mathrm{g} / \mathrm{ml}$ ) alone group and combination groups (Fig. 3D, E and E). Morphological changes showed in Fig. 3 indicated more apoptotic and necrotic events and stronger effect in combined modality than those in PDT and CBDCA alone groups.

The activation of caspase is considered to execute a major, if not essential, effect on the apoptotic processes (24). Caspase-3, a member of the caspase family of 13 aspartatespecific cysteine proteases that play a central role in the execution of the apoptotic program (25-27), is primarily responsible for the cleavage of PARP during cell death (28-30).

In this study, there was enhanced expression of cleaved form of caspase-3 and -9 for combined treatment compared to PDT and CBDCA alone (Fig. 4B and C, respectively), which implies that caspase- 3 and -9 are the major proteases involved in the apoptotic cascade induced by combined treatment. Typically, following PDT, the release of mitochondrial cytochrome $\mathrm{c}$ into the cytosol is followed by the apoptosome-mediated caspase activation cascade, leading to the apoptotic morphotype (4). Following the release of mitochondrial cytochrome $\mathrm{c}$ into the cytosol, activation of caspases-2, $-3,-6,-7,-8$ and -9 has been described for endothelial cell apoptosis treated with PDT (31). Meanwhile, in rodents the endoplasmic reticulum (ER)-associated caspase-12 has been proposed to be the initiator caspase in ER stress pathways to apoptosis. The caspase-12 activation by the stressed ER (32), which can then lead to caspase-9/ caspase-3/7 activation and apoptosis in a cytochrome $\mathrm{c}$ and Apaf-1-independent manner (33). On the other hand, the activation of caspase- 3 has been demonstrated in CBDCAinduced apoptosis in the squamous cell carcinoma cell line MIT7 (34). Therefore, the mechanism involved in combination modality may relate to the ER stress-induced apoptosis and/or mitochondrion-mediated procaspase-activation pathway, which has been demonstrated in the treatment of nasopharyngeal carcinoma cells with PDT (35).

A positive regulatory function of PARP cleavage was demonstrated in the onset of apoptosis (36). The activation of caspase-3 was also identified by the cleavage of its native substrate PARP, a commonly used measurement of caspase3-like enzymatic activity, which further confirmed the activation of caspase- 3 in the process of AMC-HN-3 cell apoptosis induced by PDT and CBDCA. As shown in Fig. 4D, there was similar expression pattern of cleaved PARP to cleaved caspase-3. The increased expression of cleaved caspase-3, -9 and PARP is consistent with an enhanced cytotoxic and apoptotic effect for combined treatment.

Overexpression of caspase-3 mRNA occurred after treatment of HL-60 leukemia cells for 3 or $6 \mathrm{~h}$ with CBDCA, while its expression was decreased after $12 \mathrm{~h}$ treatment, demonstrating that caspase-3 gene may take part in the early stages of apoptosis (37). Our results showed that the peaked expression of cleaved form of caspase-3, -9 and PARP occurred around $3 \mathrm{~h}$ after PDT (Fig. 4B, C and D, respectively), suggesting that PDT induces rapid apoptotic cell death (6).

Taken together, our results indicate that caspase-3, -9 and PARP play a vital role in the apoptosis processes of AMCHN-3 cell line induced by $9-\mathrm{HPbD}$-mediated PDT and CBDCA. There is enhanced cytotoxic and pro-apoptotic effect in this combined modality on AMC-HN-3 cells in vitro, which suggests the feasibility of combined modality and the possibility of lowering the side effects on normal cells through reducing the effective dosage of $9-\mathrm{HPbD}$ and CBDCA. The potential mechanisms involved merit further study.

\section{Acknowledgements}

This study was funded by Dankook Medical Laser and Device Regional Innovation Center.

\section{References}

1. Dolmans DE, Fukumura D and Jain RK: Photodynamic therapy for cancer. Nat Rev Cancer 3: 380-387, 2003.

2 Henderson BW and Dougherty TJ: How does photodynamic therapy work? Photochem Photobiol 55: 145-157, 1992.

3. Dougherty TJ, Gomer CJ, Henderson BW, et al: Photodynamic therapy. J Natl Cancer Inst 90: 889-905, 1998.

4. Buytaert E, Dewaele M and Agostinis P: Molecular effectors of multiple cell death pathways initiated by photodynamic therapy. Biochim Biophys Acta 1776: 86-107, 2007.

5. Moan J and Berg K: Photochemotherapy of cancer: experimental research. Photochem Photobiol 55: 889-905, 1992.

6. Agarwal ML, Clay ME, Harvey EJ, Evans HH, Antunez AR and Oleinick NL: Photodynamic therapy induces rapid cell death by apoptosis in L5178Y mouse lymphoma cells. Cancer Res 51: 5993-5996, 1991.

7. Zaidi SI, Oleinick NL, Zaim MT and Mukhtar H: Apoptosis during photodynamic therapy-induced ablation of RIF-1 tumors in $\mathrm{C} 3 \mathrm{H}$ mice: electron microscopic, histopathologic and biochemical evidence. Photochem Photobiol 58: 771-776, 1993.

8. Copper MP, Tan IB, Oppelaar H, Ruevekamp MC and Stewart FA: Meta-tetra(hydroxyphenyl) chlorine photodynamic therapy in early-stage squamous cell carcinoma of the head and neck. Arch Otolaryngol Head Neck Surg 129: 709-711, 2003.

9. Sibata CH, Colussi VC, Oleinick NL and Kinsella TJ: Photodynamic therapy in oncology. Expert Opin Pharmacother 2: 917-927, 2001.

10. Zamboglou N, Schnabel T, Kolotas C, et al: Carboplatin and radiotherapy in the treatment of head and neck cancer: six years experience. Semin Oncol 21: 45-53, 1994.

11. Stiff PJ, McKenzie RS, Alberts DS, et al: Phase I clinical and pharmacokinetic study of high-dose mitoxantrone combined with carboplatin, cyclophosphamide, and autologous bone marrow rescue: high response rate for refractory ovarian carcinoma. J Clin Oncol 12: 176-183, 1994.

12. Polee MB, Sparreboom A, Eskens FA, et al: A phase I and pharmacokinetic study of weekly paclitaxel and carboplatin in patients with metastatic esophageal cancer. Clin Cancer Res 10: 1928-1934, 2004.

13. Niitani $H$ and Kobayashi K: Cisplatin/carboplatin therapy in non-small cell lung cancer. Oncology 49: 51-56, 1992.

14. Rajeswaran A, Trojan A, Burnand B and Giannelli M: Efficacy and side effects of cisplatin- and carboplatin-based doublet chemotherapeutic regimens versus non-platinum-based doublet chemotherapeutic regimens as first line treatment of metastatic non-small cell lung carcinoma: a systematic review of randomized controlled trials. Lung Cancer 59: 1-11, 2008.

15. Skírnisdóttir I, Lindborg K and Sorbe B: Adjuvant chemotherapy with carboplatin and taxane compared with single drug carboplatin in early stage epithelial ovarian carcinoma. Oncol Rep 18: 1249-1256, 2007. 
16. Rabik CA and Dolan ME: Molecular mechanisms of resistance and toxicity associated with platinating agents. Cancer Treat Rev 33: 9-23, 2007.

17. Wernyj RP and Morin PJ: Molecular mechanisms of platinum resistance: still searching for the Achilles' heel. Drug Resist Updat 7: 227-232, 2004

18. Choi SE, Sohn S, Cho JW, Shin EA, Song PS and Kang Y: 9-Hydroxypheophorbide $\alpha$-induced apoptotic death of MCF-7 breast cancer cells is mediated by c-Jun N-terminal kinase activation. J Photochem Photobiol B 73: 101-107, 2004.

19. Kim SY, Chu KC, Lee HR, Lee KS and Carey TE: Establishment and characterization of nine new head and neck cancer cell lines. Acta Otolaryngol 117: 775-784, 1997.

20. Peng Q, Warloe T, Berg K, et al: 5-Aminolevulinic acid-based photodynamic therapy: clinical research and future challenges. Cancer 79: 2282-2308, 1997.

21. Waterfield EM, Renke ME, Smits CB, et al: Wavelengthdependent effects of benzoporphyrin derivative monoacid ring $\mathrm{A}$ in vivo and in vitro. Photochem Photobiol 60: 383-387, 1994.

22. Henderson BW, Bellnier DA, Greco WR, et al: An in vivo quantitative structure-activity relationship for a congeneric series of pyropheophorbide derivatives as photosensitizers for photodynamic therapy. Cancer Res 57: 4000-4007, 1997.

23. Matroule JY, Carthy CM, Granville DJ, Jolois O, Hunt DW and Piette J: Mechanism of colon cancer cell apoptosis mediated by pyropheophorbide-a methylester photosensitization. Oncogene 20: 4070-4084, 2001.

24. Salvesen GS and Dixit VM: Caspases: intracellular signaling by proteolysis. Cell 91: 443-446, 1997.

25. Alnemri E, Livingston D, Nicholson D, et al: Human ICE CED-3 Protease Nomenclature. Cell 87: 171, 1996.

26. Cohen G: Caspases: the executioners of apoptosis. J Biochem 326: 1-16, 1997.

27. Cryns V and Yuan J: Proteases to die for. Genes Dev 12: 15511570,1998 .

28. Nicholson DW, Ali A, Thornberry NA, et al: Identification and inhibition of the ICE/CED-3 protease necessary for mammalian apoptosis. Nature 376: 37-43, 1995.
29. Tewari M, Quan LT, O'Rourke K, et al: Yama/CPP32ß, a mammalian homolog of CED-3, is a CrmA-inhibitable protease that cleaves the death substrate poly(ADP-ribose) polymerase. Cell 81: 801-809, 1995.

30. Le Rhun Y, Kirkland J and Shah G: Cellular responses to DNA damage in the absence of poly(ADP-ribose) polymerase. Biochem Biophys Res Commun 245: 1-10, 1998.

31. Granville DJ, Shaw JR, Leong S, et al: Release of cytochrome c, Bax migration, Bid cleavage, and activation of caspases 2, 3, 6, 7, 8, and 9 during endothelial cell apoptosis. Am J Pathol 155: $1021-1025,1999$.

32. Tan Y, Dourdin N, Wu C, De VT, Elce JS and Greer PA: Ubiquitous calpains promote caspase-12 and JNK activation during endoplasmic reticulum stress-induced apoptosis. J Biol Chem 281: 16016-16024, 2006.

33. Morishima N, Nakanishi K, Takenouchi H, Shibata T and Yasuhiko Y: An endoplasmic reticulum stress-specific caspase cascade in apoptosis. Cytochrome c-independent activation of caspase- 9 by caspase-12. J Biol Chem 277: 34287-34294, 2002.

34. Itoh M, Chiba H, Noutomi T, Takada E and Mizuguchi J: Cleavage of Bax-a and Bcl-xL during CBDCA-mediated apoptosis in squamous cell carcinoma cell line. Oral Oncol 36: 277-285, 2000.

35. Mak NK, Li KM, Leung WN, et al: Involvement of both endoplasmic reticulum and mitochondria in photokilling of nasopharyngeal carcinoma cells by the photosensitizer $\mathrm{Zn}$ BC-AM. Biochem Pharmacol 68: 2387-2396, 2004.

36. Boulares AH, Yakovlev AG, Ivanova V, et al: Role of poly(ADP-ribose) polymerase (PARP) cleavage in apoptosis: Caspase 3-resistant PARP mutant increases rates of apoptosis in transfected cells. J Biol Chem 274: 22932-22940, 1999

37. Floros KV, Thomadaki H, Katsaros N, Talieri M and Scorilas A: mRNA expression analysis of a variety of apoptosis-related genes, including the novel gene of the BCL2-family, BCL2L12, in HL-60 leukemia cells after treatment with carboplatin and doxorubicin. Biol Chem 385: 1099-1103, 2004. 